Dragoş-Andrei Giulea

Milwaukee, Wisconsin, USA

\title{
SEEKING TO SEE HIM \\ AT THE FESTIVAL OF PASCHA: GLORY-SOTERIOLOGY \\ IN EARLY CHRISTIAN PASCHAL MATERIALS AND RABBINIC LITERATURE ${ }^{1}$
}

Previous scholars have undertaken seminal investigations concerning the Paschal or Pesach messianic expectations present in both Christian and rabbinic documents, as well as similar hints in the Hebrew Scriptures or pseudepigraphic writings. ${ }^{2}$ However, the present article tries to analyze the same festival from a different perspective, namely the apocalyptic one, and to focus on a particular theme, the divine glory, Shekinah, or kabod, in two of its particular aspects, namely the tradition regarding the salvific function of the kabod and its spatial descent. I would call this conception of salvation glorysoteriology or kabod-soteriology. Both themes seem to be part of old priestly traditions and preserved in the later Christian and rabbinical theologies of Pascha or Pesach. Accordingly, this article argues that both the early rabbinic materials on Pesach and the early Christian Paschal homilies of Asia Minor testify to the expectation of divine glory at the time of the Pesach/Paschal festival. The main rationale for this expectation consists of the salvific function of the divine kabod, and the festival of Pascha the privileged time for the divine descent and manifestation. Since the same expectation may be also encountered in some of the Jewish documents of the Second Temple period ascribed to Philo, the present study suggests that the rabbinic and Christian expectations of divine glory represent two different developments of a previous feature in the Second Temple festival of Pesach. Observing these materials from a mystical perspective, it seems that all of them (and even others such as the Songs of the Sabbath Sacrifice, or the Christian liturgies) reflect the existence of a form of mysticism that engages a whole community and

${ }^{1}$ The expression «Seeking to See Him» is inspired by the well-known work of April De Conick: Seek to See Him: Ascent and Vision Mysticism in the Gospel of Thomas (Leiden-New York, 1996).

${ }^{2}$ See, for example, A. Strobel, NT 2 (1958) 199-227; ZNW 49 (1958) 157-196; NTS 4 (1958): 210-215; Untersuchungen zum eschatologischen Verzögerungsproblem (Leiden, 1961); and R. Le DÉAut, La nuit pascale. Essai sur la signification de la Pâque juive à partir du Targum d'Exode XII 42 (Rome, 1963). 
not only an individual. Pascha was therefore a community-centered, not individual, form of mysticism, where the liturgical celebration represented the prescribed steps in which the mystical experience (or at least the preparation for this experience) should materialize.

\section{The Origins of Kabod-Soteriology}

Historical investigations on the origins of the Jewish festival of Pesach have not draw a definite conclusion concerning the time when the theme of the divine light became part of the Passover symbolism. While historians still debate whether the festival's origins were nomadic, semi-nomadic, pastoral or agricultural, the concept of salvation from the Egyptian slavery appears to be a further addition. ${ }^{3}$ T. Prosic generally views the light as «a sign of the act of creation» in opposition to the dark powers of the primordial chaos. ${ }^{4}$ Occurring in the first month at the vernal equinox, Pascha implies all the positive symbolisms associated with the sun and the new harvest: from order and creation, to salvation and perfection. ${ }^{5}$

Nevertheless, the connection between the vision of the divine light and the idea of salvation was a very ancient belief in Israel, as some of the protoIsaianic oracles may prove. Thus, the concept seems to go back to the preexilic time. ${ }^{6}$ A passage such as Isaiah 9:2-3 is most likely part of an oracle

${ }^{3}$ J. B. Segal, The Hebrew Passover from the Earliest Times to AD 70 (London, 1963); H. HAAG, Vom alten zum neuen Pascha. Geschichte und Theologie des Osterfestes (Stuttgart, 1971); E. Отто, Пפ פ pāsah? // TDOT. Vol. 12. 1-24; T. Prosic, The Development and Symbolism of Passover until 70 CE (London-New York, 2004). T. Prosic makes a general review of the previous theories on the origins of the festival (Prosic, 19-32). She maintains that the recent developments in the history of early Israel have eliminated the nomadic theory (Prosic, The Development and Symbolism... 32); moreover, she supports the theory of a single origin for Passover, Unleavened Bread, and Sheaf (Ibid. 69).

${ }^{4}$ Prosic, The Development and Symbolism... 99-100.

${ }^{5}$ Ibid. 83-97. A similar perspective may be encountered in Le Déaut, where he explains the later rabbinic symbolism of the Pesach: «Si la Pâque (et l'Exode) est décrite comme une sorte de création nouvelle, celle-ci s'accompagnera, comme la première, de la victoire de la lumière sur les ténèbres du chaos» (LE DÉAUT, La nuit pascale... 232).

${ }^{6}$ According to M. Smith, solar language, a common element of the Near East as early as the second millennium, developed in ancient Israel in a first stage as a general terminology for theophanic luminosity. In a second stage, monarchy played an important influence in associating the solar symbolisms with Yahweh (M. S. Sмiтh, The Bear Eastern Background of the Solar Language for Yahweh // JBL 109/1 (1990) 29-39). Cf. Segal, The Hebrew Passover...; Prosic, The Development and Symbolism...; H. P. StÄHLI, Solare Elemente im Jahweglauben des Alten Testaments (Freiburg-Göttingen, 1985) (OBO, 66); B. LANGER, Gott als «Licht» in Israel und Mesopotamien: Eine Studie zu Jes. 60:1-3.19f. (Klosterneuburg, 1989) (Öster- 
related to the Assyrian invasion between 734 and 732 BC when Tiglath-pileser III annexed three Samarian provinces to Assyria: the Way of the Sea, Trans-Jordan, and Galilee of the nations (i.e., Dor, Megiddo, and Gilead). ${ }^{7}$

The people who walked in darkness (חשך) have seen a great light (אור); those who lived in a land of deep darkness - on them light (אור) has shined. You have multiplied the nation, you have increased its joy; they rejoice before (פנים = face) you. ${ }^{8}$

It seems that the proto-Isaianic oracles unveil a large and democratic accessibility to the vision of divine glory, which probably represented the general expectation of the entire people of Israel. The meaning of this democratic accessibility to divine glory is rooted in its salvific power. Isaiah 9:2-3 seems to be, therefore, one of the first testimonies that reflect the fact that the oldest attested Jewish theological conception of the vision of God's glory envisages this event as presupposing the manifestation of salvific power. Other passages with the same soteriological emphasis, either in the Isaianic texts or in psalms, seem to be a later, post-exilic development.

The prophetic text appears to make a reference in chapter 9 to a future time, when the people of Israel will be saved from the Assyrian oppression and will be elevated to the highest and happiest possible status: to be in the light (פור) of Yahweh and see his face (פנים). In addition, the well-known Jewish tradition that identifies God's glory with his face can be encountered in this context. One can see a few verses further that the salvific status will not be just a temporary phenomenon but one extended without limit into the future. It will be a kingdom of Davidic descent, led by a child who is an «everlasting

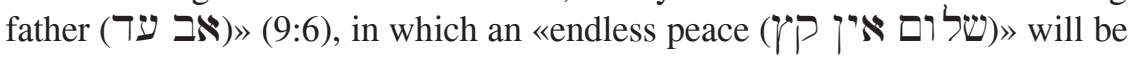
established and justice and righteousness will be instituted «from this time onward and forevermore (ע) (עד) (9:7). Consequently, all these descriptions of the future salvation highlight the eschatological aspect of the text.

According to the Isaianic author, in the eschatological times the people of God will acquire the luminous or glorious characteristics of Yahweh. While 6:3 describes Yahweh as «luminous» («Holy [קדרש], Holy, Holy, is the Lord of hosts; the whole earth is full of his glory [כבוד]

reichisches biblische Studien, 7); J. G. TAYLOR, Yahweh and the Sun: Biblical and archaeological evidence for sun worship in ancient Israel (Sheffield, Engl., 1993). See also the authors from the note 7.

${ }^{7}$ E. D. Kissane, The Book of Isaiah (Dublin, 1960), 104. R. E. Clements, Isaiah 1-39 (London, 1980), 34; J. D. W. WATTs, Isaiah 1-33 (Waco, 1985) (World Biblical Commentary, 24) 133-134; J. J. Collins, Isaiah (Collegeville, 1986) 106; H. WILDBERGER, Isaiah 1-12. A Commentary (Minneapolis, 1991) 394.

${ }^{8}$ Isa 9:2-3 [NRSV translation for the present study].

9 קדש does not have only the meaning of «separated», which is probably a later development; its root — P - also carries the meaning of «bright», an adjective 
attribute to the eschatological human condition: «On that day the branch of the Lord (Yahweh) shall be beautiful and glorious (דבコ)». The glory is also a central element of the soteriological geography in which certain terrestrial and sacred places, such as the mount of Zion or the city of Jerusalem, represent the inhabited domains of salvation:

Whoever is left in Zion and remains in Jerusalem will be called holy (קדרש), everyone who has been recorded for life in Jerusalem ... The Lord will create over the whole site of Mount Zion and over its places of assembly a cloud by day and smoke and a shining (נגד) of a flaming fire by night. Indeed over all the glory (כבר) there will be a canopy. ${ }^{10}$

The fragment 46:13, which is part of the deutero-Isaianic corpus, reflects even more clearly the connection between salvation, glory, and a special geography of salvation: «I will put salvation (תשוער) in Zion, for Israel my glory (Пาผコת)».

The idea of sacred geography is important for every religious manifestation, because it implies search, pilgrimage, procession, and festival. ${ }^{11}$ Thus, the theme of procession towards the divine light may be encountered in the second chapter of Isaiah: «O house of Jacob, come, let us walk in the light of the Lord» (2:5). 2:3 may also be a good example for the idea of procession to the sacred mountain of the Lord where his temple is located: «Come, let us go up to the mountain of the Lord, to the house of the God of Jacob; that he may teach us his ways and that we may walk in his paths». However, a key text where the concepts of light and salvation start being connected with a certain festival for Yahweh seems to be the deutero-Isaianic passage of 33:2022, written probably at the time of the Second Temple:

Look on Zion, the city of our appointed festivals! Your eyes will see Jerusalem, a quiet habitation, an immovable tent, whose stakes will never be pulled up, and none of whose ropes will be broken. But there the Lord in majesty (ריץ) will be for us a place of broad rivers and streams, where

used especially for divinity and the things related to the divine. (W. KoRNFELD, H. RINGGREN, קדש qdš // TDOT. Vol. 12. 521-545).

${ }^{10}$ Isa 4:3-5. Cf. Isa 28:5: «In that day the Lord of hosts will be a garland of glory

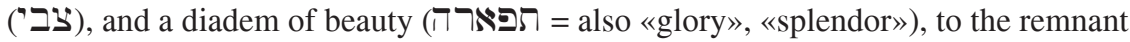
of his people». Cf. Isa 33:20-21. Another ancient text, the fragment of Exodus 15, generally called the Song at the Sea, sees salvation as an eternal dwelling in Yahweh's sacred sanctuary; Exod 15:17-18: "You brought them and planted them in the mountain of your own possession, the place (מברן), O Lord (Yahweh), that you made your abode (בישבי), the sanctuary (מקדש), O Lord, that your hands have established. The Lord will reign forever and ever (ע) (עד)».

${ }^{11}$ Cf. M. Eliade, Patterns in Comparative Religion (New York, 1958); IDEM, The Sacred and the Profane: The Nature of Religion (New York-Harcourt-Brace, 1959); IDEM, Images and Symbols: Studies in Religious Symbolism (New York, 1961). 
no galley with oars can go, nor stately ship can pass. For the Lord is our judge, The Lord is our ruler, the Lord is our king; he will save (שישי ) us.

The book of Psalms discloses a similar perspective of salvation in the glory of Yahweh, as one can see, for example, in Psalm 68. Moreover, the context of Psalm 68 does not appear to be an ordinary Temple service (like probably those of $26 ; 27 ; 63: 2 ; 68: 35$; or 99 ), but a special festival where an embedded procession represents a significant ingredient of the celebration:

7/O God (אל הים), when you went out before your people, when you marched through the wilderness, /8/ the earth quaked, the heavens poured down rain at the presence (פנים) of God, the God of Sinai, at the presence (פנים) of God, the God of Israel. / ...24/ Your solemn processions (הליכה) are seen, O God, the processions of my God, my King, into the sanctuary (קדשש 1 ) $125 /$ the singers in front, the musicians last, between them girls playing tambourines.

While in Psalms 67:1-2, 80:3, and 80:7 God's shining face or presence (פנים) procures salvation (ישועה), Psalm 104 makes clear that the manifestation of פנים is the way God grants life to all creatures. ${ }^{12}$ Most likely, the central significance of the visio Dei in the Isaianic and Psalmic corpora is the salvation of the people of Jerusalem, and for this reason the expectation of visio Dei probably becomes a key social feature. Speaking about the light of theophany in the Old Testament, Aalen states: «The primary purpose of the theophany of God is the deliverance and salvation of the nation and of the individual». ${ }^{13}$

Certainly, the manifestation of God's glory in the books of Isaiah and Psalms may include other functions, such as punishing the enemies, or proving that God is the ultimate source of knowledge, kingship, judgment, or lawgiving. ${ }^{14}$

${ }^{12}$ Ps 104:29-31: «You hide your face (פניםם), they [the living creatures — my note] are dismayed; when you take away their breath (רוח), they die and return to their dust. You send forth your spirit (רוח), they are created; and you renew the face (פנים) of the ground. Let the glory (כבוד) of the Lord (Yahweh) endure forever».

${ }^{13}$ TDOT. Vol. 1. 165. On page 161, Aalen has the following remark: «The situation is the same when the OT speaks of 'the light of Yahweh' (Isa 2:5), 'his (God's) light' or 'lamp' (Job 29:3), or in the same sense, of 'the light' (Ps 36:10[9]; 43:3). Here too light is to be understood as a symbol not of God's person, but of the salvation which God gives».

${ }^{14}$ The punitive function, for example, is closely connected to the concept of salvation, as long as Yahweh himself is the agent of salvation, and the liberation from the enemies' oppression implies a salvific act. Seeing his glory, the enemies «enter into the rock, and hide in the dust from the terror of the Lord (Yahweh), and from the glory (הדר) of His majesty (גאוג)» [Isa 2:10]. The same expression, «the terror of

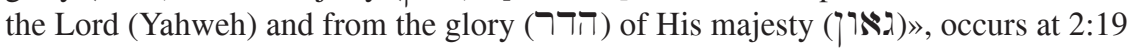
and $2: 21$. The same theme, though differently expressed, appears in 10:16-18; 19:1; 
The evidence above suggests that the connection between salvation and the vision of the divine glory has a venerable history, being probably conveyed as early as the time of the First Temple. In addition, some texts pertaining to the Second Temple period such as Isaiah 33 and Psalm 68 seem to illustrate the connection between these two ideas and particular Jewish festivals.

At the same time, special attention should be paid to the original location of the divine kabod and its spatial movements. Salvation appears to involve a particular movement from the original location of divine glory to the new location of its manifestation, specifically to the place where the glory enacts its salvific operations. The old Hebrew references appear to be divided into two traditions. First, some texts such as Isaiah 2:3-5 and Ezekiel 1, 8, or 10 seem to talk about a terrestrial location, the Temple of Jerusalem or the river Chebar. At least for Isaiah, however, it is more plausible to conceive the divine manifestation of the kabod as a descent rather than a horizontal movement, because the Temple is placed on a mountain. ${ }^{15}$ A second tradition seems to be quite clear in representing the divine kabod as descended from above. The narrative about the consecration of Solomon's temple may be a good example of this tradition:

When Solomon had ended his prayer, fire came down from heaven

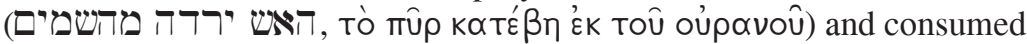
the burned offering and the sacrifices; and the glory (כבוד, סó $\xi \alpha)$ of the Lord filled the temple. The priests could not enter the house of the Lord, because the glory (כבוד, סó $\delta \alpha$ ) of the Lord filled the Lord's house. When all the people of Israel saw the fire come down and the glory (כבוד, סó $\delta \alpha$ ) of the Lord on the temple, they bowed down on the pavement with their faces to the ground, and worshiped and gave thanks to the Lord. ${ }^{16}$

\section{The Second Temple Passover and the Expectation of the Divine Light}

A significant question can be raised about the time when the two ideas of the vision of divine light and salvation started being associated with the festival of Pesach. Several of the books ascribed to Philo of Alexandria seem to support the hypothesis that the connection was already functional at the time

הוד 26:21; 28:5; 31:7, 30; 33:2,3,6,11-12. As the psalm 104:1 shows, the terms of (splendor) and (glory, majesty) seem to refer to Yahweh's garments.

${ }^{15}$ See also Deut 33:2: «Lord came from Sinai, and dawned from Seir upon us; he shone forth from Mont Paran».

${ }^{16} 2 \mathrm{Chr}$ 7: 1-3. Likewise, in the paradigmatic theophany on Mount Sinai, Moses sees Yahweh descending on the mount in order to disclose the divine command-

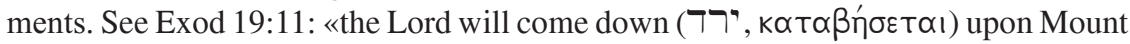

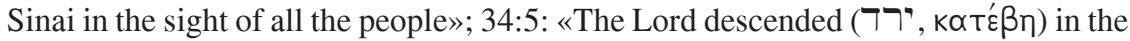
cloud and stood with him there, and proclaimed the name, 'The Lord'». 
of the Second Temple. In the second part of his De specialibus legibus, while describing the «ten feasts which are recorded in the law», ${ }^{17}$ Philo explains why Pascha falls on the fifteenth day of the first month. At that time light is an uninterrupted phenomenon of two days, the sun enlightening all the day of the fourteenth and the moon all the night of the fifteenth (i.e., in our modern calendar the day of $14^{\text {th }}$ and the night of $14^{\text {th }}$ to $15^{\text {th }}$ ):

The feast begins at the middle of the month, on the fifteenth day, when the moon is full, a day purposely chosen because then there is no darkness, but

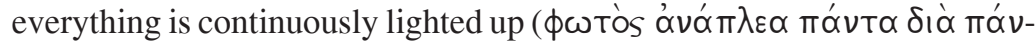
$\tau \omega v)$ as the sun shines from morning to evening and the moon from evening to morning and while the stars give place to each other no shadow is cast

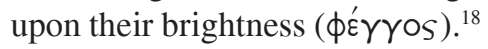

The element of light was therefore an important part of the feast. Nevertheless, light was not only a physical or cosmological event, but also one pertaining to the spiritual domain, and the first part of the treatise Questions and Answers on Exodus is of significant help in showing this idea. This treatise contains a commentary on Exodus 12, which represents the foundational biblical passage for Philo's commentaries on Passover, as well as for the «rabbinic» targums and early Christian Paschal homilies. In its core narrative, the passage reads as follows:

The Lord (יהוד) said to Moses and Aaron in the Land of Egypt: This month shall mark for you the beginning of months; it shall be the first month of the year for you. Tell the whole congregation of Israel that on the tenth of this month they are to take a lamb for each family, a lamb for each household. [...] You shall keep it until the fourteenth day of this month; then the whole assembled congregation of Israel shall slaughter it at twilight. They shall take some of the blood and put it on the two doorposts and the lintel of the houses in which they eat it. They shall eat the lamb that same night; [...] It is the Passover (פסח) of the Lord (ידוה). For I will pass through the land of Egypt that night. [...] I am the Lord (פסוד) ידוד). [...] This day shall be a day of remembrance for you. You shall celebrate it as a festival (חי) to the Lord (יהוד). ${ }^{19}$

One can easily understand from this fragment the basic facts of the paschal story: Yahweh lets Moses and Aaron know about his coming and asks them to further inform the people of Israel to be prepared for such a crucial

${ }^{17}$ Philo, Spec. 2,41, in Philo VII (Trans. F. H. Colson (Cambridge, 1984) (LCL,

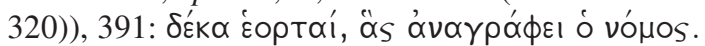

${ }^{18}$ Spec. 2,155. Cf. $Q E$ 1,9: «(Exod 12:6a) Why does He command (them) to keep the sacrifice until the fourteenth (day of the month)? [...] For when it has become full on the fourteenth (day), it becomes full of light in the perception of the people». (Philo. Supplement II (Trans. R. Marcus (Cambridge, 1987) (LCL, 401) 17).

${ }^{19}$ Exod 12:1-14. 
encounter with his God. They must keep aside a chosen lamb for a period of four days and slaughter it afterwards in the twilight of the fourth day; Yahweh will come that night. A particular aspect that needs to be underlined is the tension of the high, if not the highest possible, expectation, namely that of God's coming. Due perhaps to its central importance, both the Pesach and Paschal festivals will preserve this tension of expectation, as long as a similar feature may be encountered either in Christian homilies or in rabbinic materials. However, Philo's book may be viewed as a first treatise on the paschal tradition, the key difference from future Christian approaches being that he uses a spiritual rather than a typological reading. The Christian homilists will conceive a difference between the old and the new Pascha, using a typological interpretation, while Philo offers an allegorical interpretation and envisions Passover as the passage from the sensible to the intelligible realm, from the literal meaning (Tó j́ntóv) of the text to its deeper sense according to

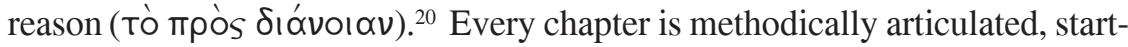
ing with an initial, literal reading and continuing with a second reading, which is an intelligible, allegorical, or dianoetical explanation. At this second level, the Passover represents the progress (прокоти́) of the soul, and most likely its culmination consists of reaching illumination: ${ }^{21}$

For when the souls appear bright and visible, their visions begin to hold festival, hoping for a life without sorrow or fear as their lot and seeing the cosmos with the weight of the understanding as full and perfect, in harmony with the decade. ${ }^{22}$

A passage from De congressu quaerendae eruditionis gratia summarizes the articulation of all these key ideas of Passover, progress of the soul, and illumination:

We find this «ten» plainly stated in the story of the soul's Passover, the crossing ( $\delta ı \alpha \beta \propto \sigma ı s)$ from every passion and all the realm of sense to the tenth, which is the realm of mind and God; for we read «on the tenth day of this month let everyone take a sheep for his house» (Exod xii.3), and thus beginning with the tenth day we shall sanctify to Him that is tenth the offering fostered in the soul whose face have been illumined ( $ா \varepsilon \phi \omega \tau і \sigma \mu \varepsilon v \eta)$ through

${ }^{20} Q E 1,4$. The soul and the mind have to pass from the vicious function to the virtuous one, and ultimately the soul has to overcome the body, the mind has to overcome the senses, while the thoughts have to become prophetic. Cf. Spec. 2,147 where

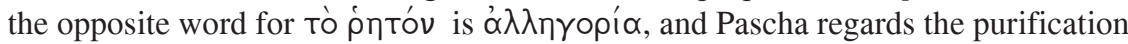
of the soul.

${ }^{21} Q E 1,3 ; 1,7$; and 1,11 .

${ }^{22} Q E$ 1,2 (Trans. R. MARCus (LCL, 401) 8). The same perspective is also expressed a few pages further in the eighth chapter: «First it [the soul which desires perfection] was necessary to pluck out sins and then to wash them out and, being resplendent, to complete the daily (tasks) in the practice of virtue». (QE 1,8; MARCUS, 17). 
two parts out of three, until its whole being becomes a brightness ( $\phi^{\prime} \dot{\gamma} \gamma \gamma O S$ ), giving light to the heaven like a full moon by its increase in the second week. And thus it will be able not only to keep safe, but to offer as innocent and spotless victims its advances on the path of progress (прокотаí). ${ }^{23}$

Thus, envisioning the Paschal festival as the progress (трокотп́) of the soul on the way toward illumination or meeting God, the Philonian passages illustrate that the expectation of the Paschal enlightenment was a lively practice during the Second Temple period. In addition, it is also important to note that Philo concocted the whole visionary argument in an internalized form, namely as the progress of the soul. The internalized way to illumination parallels the cosmic growth of the moon from two-thirds on the tenth day of Nissan to the full moon on the fourteenth. Thus, the Alexandrian depicts the dynamic of the spiritual advancement and of the gradual illumination of the soul to the completion of its entire brightness ( $\phi^{\prime} \hat{\varepsilon}_{\gamma} \gamma \mathrm{OS}$ ) in the context of the Passover festival. ${ }^{24}$ This dynamic will also be present, in a different form, in Melito and Pseudo-Hippolytus.

\section{The Mediation of the New Testament: Identifying Christ with the Divine Kabod}

The central distinction between the Jewish Pesach and the Christian Pascha is primarily a matter of theology, consisting of the Christian identification of Yahweh or of the divine kabod with Jesus Christ. This process is already present in the Christian documents of the first century pertaining to the New Testament, and some scholars consider it as originating within the religious or liturgical practice of the first Christian century. ${ }^{25}$ The theological position ascribing a divine or godly nature to Jesus Christ is usually called «high Christology».

The process of identifying Jesus Christ with Yahweh can be encountered, for example, in 1 Corinthians 2:8, where Christ receives the title of the «Lord

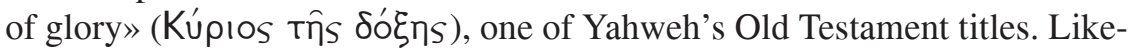
wise, after the narrative of the events of Epiphany and Christ's temptations in the wilderness, Matthew 4:13-16 connects Christ's first kerygmatic actions to the salvific intervention of the divine light promised in Isaiah 9:1-2:

${ }^{23}$ Philo, Congr. 106, in Philo IV (Trans. F. H. Colson, G. H. Whitaker (Cambridge, 1985) (LCL, 261) 511).

${ }^{24}$ For the theme of progressive illumination of the soul in Philo, see also Spec. 2,145-149 and $Q E 1,7-8$.

${ }^{25}$ See, for example, L. Hurtado, One God, One Lord: Early Christian Devotion and Ancient Jewish Monotheism (London-New York, 1998), or IDEM, Lord Jesus Christ: Devotion to Jesus in Earliest Christianity (Grand Rapids, 2003) and R. BAUCKHAM, God Crucified: Monotheism and Christology in the New Testament (Grand Rapids, 1998). 
He left Nazareth and made his home in Capernaum by the sea, in the territory of Zebulun and Nephtali, so that what had been spoken through the prophet Isaiah might be fulfilled: «Land of Zebulun, land of Nephtali, on the road by the sea, across the Jordan, Galilee of the Gentiles - the people who set in darkness have seen a great light, and for those who set in the region and shadow of death light has dawned».

Matthew 1:22-23 also identifies the newborn Christ with the character of the newborn Emmanuel found in Isaiah 7:14. In addition, in the narrative about the presentation in the Temple in Luke 2:28-32, Simeon, the old man who receives Christ in his hands, pronounces the following oracle: «My eyes have seen your salvation which you have prepared before the face of all peoples, a light ( $\phi \hat{\omega} s$ ) for revelation to the nations, and the glory ( $\delta$ ó $\xi \alpha$ ) of your people Israel». ${ }^{26}$

Also important for this investigation is the fact that the Gospel according to John depicts the event of the Incarnation as the coming of the divine light, therefore using glory-terminology. After identifying in 1:4 the Word with «life» and «life» with «light», in a similar fashion to the Targum Neofiti 1, the Gospel states in 1:9 that «[t]he true light, which enlightens everyone, was coming into the world». Besides this, while in 1:14 the apostle testifies that disciples have seen Christ's glory ( $\left.\delta \delta^{\prime} \xi \alpha\right)$, in 8:12, 9:5 and 12:35-36,46 gives witness that Christ defines himself as the light of the world (Tò $\phi \hat{\omega} s$ тoû kóouou), or the light that came into the world. The glory-language which depicts Christ's Incarnation as the descent of the divine kabod was therefore commonplace as early as the first century AD, and the soteriological intention of this coming was an integrated element.

Finally, the Book of Revelation does not associate the salvific glory with the event of Incarnation but with the eschatological reality of the heavenly kingdom. Thus, 21:23-24 states that «the city has no need of sun or moon to shine on it, for the glory of God is its light, and its lamp is the Lamb. The nations will walk by its light, and the kings of the earth will bring their glory into it». Consequently, salvation comes through the divine kabod and the state of salvation is conceived of as existing within the glory of God. Likewise, the distinctive element of the Christian glory-soteriology consists of the identifying Jesus Christ with the kabod.

\section{Glory-Soteriology at the Paschal Festivals of Asia Minor}

Christian paschal theology will apropriate the identification between Jesus Christ and the divine kabod and will develop it as one of its central tenets. The Melitonean Peri Pascha together with the anonymous paschal homily entitled In sanctum Pascha probably represent the most ancient Christian

\footnotetext{
${ }^{26} \mathrm{I}$ am indebted for this idea to Fr. Alexander Golitzin.
} 
paschal texts. ${ }^{27}$ According to several scholars, 1 Peter and the Epistle of Barnabas appear to be good candidates as well. ${ }^{28}$ However, the two paschal homilies associate the festival of Pascha with the descent of the heavenly Christ as glory ( $\delta o ́ \xi \alpha)$. Sometime between A.D. 169 and 177, Melito, bishop of Sardis, was the petitioner of an apology to the emperor Marcus Aurelius on behalf of his fellow Christians. Although the apology has been lost, this event helps modern scholars to locate the activity of the Sardisian bishop in the second century A.D. ${ }^{29}$ In his only extant book, Peri Pascha, Melito utters:

[T] he temple below was precious, but it is worthless now because of the Christ above. The Jerusalem below was precious, but it is worthless now because of the Jerusalem above [...] For it is not in one place (Tómos) nor in a little plot that the glory ( $\delta \hat{\sigma}^{\prime} \alpha$ ) of God is established (literally «enthroned», $k \alpha \theta$ ' $\delta \rho u \tau \alpha ı)$, but on all the ends of the inhabited earth his boun-

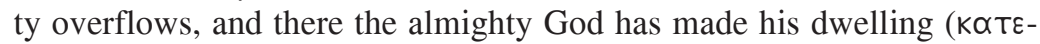

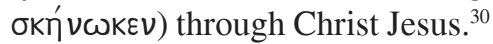

This fragment recalls the text of Revelation 21, which gives a picture of the heavenly Jerusalem descending to earth. The difference primarily consists of the fact that Christ's divine descent as glory is not temporally situated at the end of time, but in a well-specified present time, «now» ( $v \hat{v} v-$ emphatically repeated in the previous verses), which most likely refers to the paschal celebration when the homilist declaims his oeuvre. Furthermore, the divine kabod, usually depicted as sitting on the divine throne, appears in the homily as enthroned on the entire earth and overflowing earth's boundaries. It is also noteworthy that Melito articulates his discourse on Pascha in terms and images related to the descent and terrestrial activity of the Lord, first within the events of the Old Testament, which are the types of the events of the New Testaments, and then in terms and images related to the Incarnation, Passion, and salvation:

It is he who, coming from heaven to the earth because of the suffering one, and clothing himself in that same one through a virgin's womb, and coming forth a man, accepted the passions of the suffering one through the

${ }^{27}$ See R. Cantalamessa, I piu antichi testi pasquali della Chiesa. Le omelie di Melitone di Sardi e dell' Anonimo Quartodecimano e altri testi de II secolo. Introduzione, traduzione e commentario (Rome, 1972).

${ }^{28}$ See the hypothesis that L. W. BARNARD proposed in his The Epistle of Barnabas - A Paschal Homily? // VC 15 (1961) 8-22, as well as that from F. L. CRoss, I Peter, A Paschal Liturgy? (London, 1954).

${ }^{29}$ S. G. Hall, introduction to Melito of Sardis, On Pascha and Fragments / Trans. S. G. Hall (Oxford, 1979) xii and xv.

${ }^{30}$ Melito of Sardis, Peri Pascha $[$ PP] 44-45 // Ibid. 23. The present study follows this critical edition. 
body which was able to suffer, and dissolved the passions of the flesh; and by the Spirit which could not die he killed death the killer of men. ${ }^{31}$

In a different passage, which is almost identical with the saying found in Mishnah Pesachim 10,5, Melito also projects the ideas of light and salvation on the Paschal event:

It is he that delivered us from slavery to liberty, from darkness to light, from death to life, from tyranny to eternal royalty, and made us a new priesthood and an eternal people personal to him. He is the Pascha of our salvation. ${ }^{32}$

The other paschal document, In sanctum Pascha, begins with the following words:

Now is it the time when the light of Christ sheds its rays; ${ }^{33}$ the pure rays ( $\phi \omega \sigma \tau \hat{T} \rho \varepsilon s)$ of the pure Spirit rise and the heavenly treasures of divine glory $(\delta \circ \xi \alpha)$ are opened up. Night's darkness and obscurity have been swallowed up, and the dense blackness dispersed in this light of day; crabbed

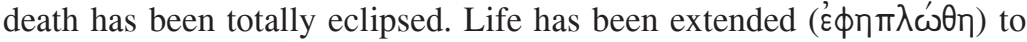
every creature and all things are diffused in brightness $(\phi \hat{\omega} s)$. The dawn

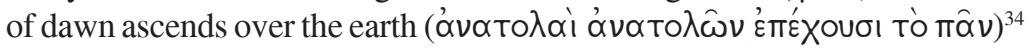
and he who was before the morning star and before the other stars, the mighty ( $\mu \varepsilon^{\prime} \gamma \alpha_{S}$ ) Christ, immortal and mighty (по入ús), sheds light brighter than the sun on the universe. ${ }^{35}$

The document is an anonymous homily of Greek language that has survived over the centuries among the manuscripts ascribed to two widely known

${ }^{31}$ PP 66 [451-458]; cf. 46-47 [303-310].

${ }^{32}$ Melito of Sardis, PP 68 [473-480]. In one of his articles, S.G. Hall studied this Melitonian passage in parallel with two Jewish texts, namely Mishnah Pesachim 10,5 and Exodus Rabbah 12,2 (cf. S. G. Hall, Melito in the Light of the Passover Haggadah // JTS n.s. 22 (1971) 29-46).

${ }^{33}$ Halton's expression «the blessed light of Christ sheds its rays» might be changed

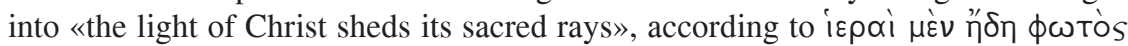

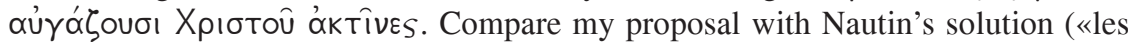
rayons sacrés de la lumière du Christ resplendissent» - Homélies Pascales / Ed. P. NAutin (Paris, 1950) (SC, 27) 116) and that offered by Visonà: «brillano i sacri raggi della luce di Cristo»(G. VIsonÀ, Pseudo Ippolito, In sanctum Pascha / Studio, edizione, commento (Milano, 1988) 231). For the Greek text, the present study follows Pierre NAutin's edition, Homélies Pascales... 170 (In sanctum Pascha [IP] 1,1). Cf. Visonà, Pseudo Ippolito...

${ }^{34}$ For the economy of the present study, it would be significant to mention that Nautin translated the Greek noun tò mầ $\nu$ through «l'univers» (Homélies Pascales... 116), while Visonà rendered it through «l'universo» (Visonà, 231).

${ }^{35}$ A. Hamman (ed.), The Paschal Mystery. Ancient Liturgies and Patristic Texts / Trans. T. Halton (Staten Iland, 1969) 50. Cf. Homélies Pascales... 170. 
Christian theologians: Hippolytus of Rome and John Chrysostom. Modern scholars started to raise questions about the authorship of this document as early as the nineteenth century when the homily's setting in Migne's collection was among the Chrysostomian dubia. However, there is not a consensus among scholars regarding the time when this text appeared. ${ }^{36}$

Ps-Hippolitus speaks more clearly about the descent of the divine light at the time of the Paschal celebration. In fact, as the homilist states in the opening phrase of the hymn, the Pascal night is the moment of Christ's coming $\left(\varepsilon \pi \mid \delta \eta \mu^{\prime} \alpha\right)$, when the border between heaven and earth is removed and the divine grace stored in heaven probably from the first day of creation, floods the whole universe: «the heavenly treasures of the divine glory $\left(\delta \delta^{\prime} \xi \alpha\right)$ are opened up». ${ }^{37}$ The light of the glory $(\delta o ́ \xi \alpha)$ of Christ, which illumines the heavenly Jerusalem in the Revelation 21, is now spread over the entire cosmos: «...the blessed light of Christ sheds its rays [...] the mighty Christ, immortal and mighty, sheds light brighter than the sun on the universe (Tò $\pi \hat{\alpha} v) \gg .{ }^{38}$

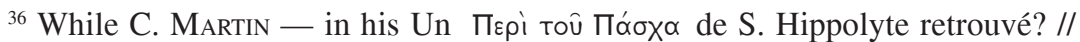
Recherches de science religieuse 16 (1922) 148-165 — thought that the homily might be the lost Hippolytan On Pascha, M. Richard considered it monarchianist: Une homélie monarchienne sur la Pâque // SP III.78 (1961) 284. In his introduction to Homélies Paschales... 46-48, P. NAUTin presumed that the homily might have been composed in the fourth century CE. On the contrary, R. CANTALAMESSA pointed to an author from the Asia Minor of the end of the second century: L'Omelia «In S. Pascha» dello Pseudo-Ippolito di Roma. Ricerche sulla teologia dell'Asia Minore nella seconda meta del II secolo (Milano, 1967) 187-368. On the one hand, Gribomont, Stuiber, and Visonà acted with prudence in dating the homily: J. GRIBOMONT // RSLR 5 (1969) 158-163; A. STUIBER // Theologische Revue 66 (1970) 398; VISONÀ, PseudoIppolito... 35-36. On the other hand, Botte, Daniélou, Grillmeier, Simonetti, Hall, Richardson, Mara, Blanchetière, and Mazza embraced Cantalamessa's position, and Kretschmar considered that the homily is a document resonating with the beginning of the third century. See B. Botte // Recherches de théologie ancienne et médiévale 33 (1968) 184; J. DANiÉLou // RSR 57 (1969) 79-84; A. GrILlmEIER // Theologie und Philosophie 44 (1969) 128-130; M. SimonetTi // Vetera Christianorum 6 (1969) 218 220; S. G. Hall // JTS 20 (1969) 301-304; G. Kretschmar, Christliches Passa im 2. Jahrhundert und die Ausbildung der christlichen Theologie // RSR 60 (1972) 306307; C. C. Richardson, A New Solution to the Quartodeciman and the Synoptic Chronology // JTS 24 (1973) 77; M. G. MARA, Évangile de Pierre (Paris, 1973) (SC) 215; F. Blanchetière, Le christianisme asiate aux $\mathrm{II}^{\mathrm{e}}$ et $\mathrm{III}^{\mathrm{e}}$ siècles (Lille, 1981) 185; E. MAzZA, Omelie pasquali e birkat ha-mazon: fonti dell'anafora di Ippolito? // EL 97 (1983) 409-481. Finally, in the most recent investigation, Gerlach maintains that IP should be associated with the Paschal tradition conveyed in third century Asia Minor. K. Gerlach, The Antenicene Pascha. A Rhetorical History (Leuven, 1998) 161, 387, 403.

${ }^{37}$ Hamman, The Paschal Mystery... 50. IP 1,1.

${ }^{38}$ Ibid. 
Pseudo-Hippolytus also uses the languages of the Incarnation to describe the Pascha, and depicts this moment as the descent of divine glory. ${ }^{39}$ Hence, expressed in the same glory-language, Pascha does not seem to be a very different sort of event than that of the Incarnation. Furthermore, the Paschal expectation of the divine kabod has also been closely connected to, or even identical with, the expectation of the Parousia. For example, Tertullian affirms that the event of Parousia will likely occur during the celebration of Pentecost. ${ }^{40}$ While the Epistula Apostolorum 17 places the same eschatological event between the Pentecost and the festival of Azymes, the Vatican codex of the Gospel of the Hebrews reads that the final judgment will take place during the eight paschal days ${ }^{41}$ However, two of the most significant testimonies of the Paschal expectation are preserved in Lactance and Jerome. Lactance, in his Divinae institutiones 7.19.3, written after A.D. 313, states that Christians celebrate the paschal night by a vigil because of the coming (adventum) of the king and God. ${ }^{42}$ In a similar, although more obvious way, Jerome affirms in his Commentary on Matthew 4.25.6 that, according to a Jewish tradition, Christ will come during the night of Pascha as the Lord came in Egypt, following the angel of death during the night. This particular expectation seems to be, according to Jerome, the theological reason for the «apostolic tradition» of not dismissing the community before the midnight of the Paschal celebration.

\section{Rabbinic Expectations of the Divine Light at the Passover Night}

One of the Mishnahic sayings ascribed to Rabbi Gamaliel, a saying later taken over into the final prayer of the Haggadah for Pesach, depicts the Passover as a passage from darkness to light and from servitude to salvation:

He brought us forth from slavery to freedom, from sorrow to joy, from mourning to festivity, from darkness to great light, and from servitude to redemption! ${ }^{43}$

${ }^{39}$ For him, the Incarnation was both a coming (' $\varepsilon \pi ı \delta \eta \mu i^{\prime} \alpha, I P$ 43-44) of Christ, who is the eternal priest, the King of glory, and the Lord of the powers (IP 46), and a compression of the magnitude of divinity in a human form (IP 45).

${ }^{40}$ De baptismo 19.2.

${ }^{41}$ Cod. Vat. Reg. Lat. 49, from R. Cantalamessa, La Pâque dans l'Eglise ancienne (Berne, 1980) 30.

${ }^{42}$ Haec est nox quae a nobis propter adventum regis ac dei nostri pervigilio celebratur (Ed. S. BRANDT (Praga-Wien-Leipzig, 1890) (CSEL, 19) 645).

${ }^{43}$ Mishnah Pesachim X, 5 // The Mishnah: Seder Moed / Ed. N. Scherman, M. Zlotowitz. Vol. II (Brooklyn, NY, 1985) 217. Cf. E. D. Goldschmidt, The Passover Haggadah: Its Sources and History (Jerusalem, 1960). See also Mishnah, Exodus Rabbah 12:2. 
In its turn Codex Neofiti 1, makes obvious the expectation of divine glory during the night of Passover. Exodus 12:23 («For the Lord will pass through to strike down the Egyptians...») appears in the Targum in the following form:

And the Glory of the Shekinah of the Lord (איקר שכינתיאו דייי) will pass to blot out the Egyptians; and he will see the blood upon the lintel and upon the two doorposts and he will pass by, and the Memra of the Lord will defend the door of the fathers of the children of Israel. $^{44}$

It is significant to note how the text brings into the paschal play a new character, the Memra (מימר) or the Word of Yahweh. It is also worth noting the change of Exodus 12:12-13 from the biblical «For I will pass through the land of Egypt that night ... I am the Lord... [W] [Wen I see the blood, I will pass over you» to the targumic «I will pass in my Memra (מימר) through the land of Egypt this night of the Passover ... I in my Memra will defend you». ${ }^{45}$ It appears that, for the targumic writer, the divine agent that is manifest or acting within the world is not Yahweh any more, but the Word of Yahweh, or Yahweh through his Word.

For the purpose of the present study it is also significant that the targumic fragment corresponding to Exodus 12:42 identifies the Word (Memra) with the Light of the first day of creation. ${ }^{46}$ Hence, the whole targumic passage summarizes Yahweh's gradual manifestation within the history of the world:

The first night: when the Lord was revealed over the world to create it. The world was without form and void, and darkness was spread over the face of the abyss and the Memra of the Lord (ממריה דייי) was the Light (נהורא), and it shone; and he called it the First Night. The second night: when the Lord was revealed to Abram ... The third night: when the Lord

${ }^{44} \mathrm{Tg}$. Neof. 12:23, in M. McNamara, R. Hayward, Targum Neofiti 1: Exodus (The Aramaic Bible. The Targums. Vol. 2) (Collegeville, 1994) 49. For the Aramaic text, see A. D. Macho, Neophiti 1. Targum Palestinense Ms de la Biblioteca Vaticana (Tomo II Exodo) / Trans. M. McNamara, M. Maher (Madrid-Barcelona, 1970), 439. See also M. Jastrow, A Dictionary of the Targumim, the Talmud Babli and

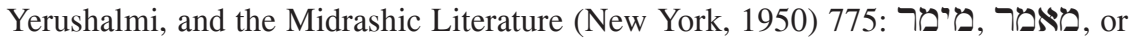

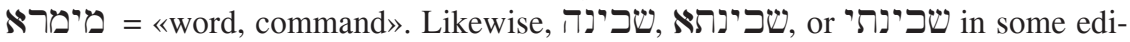
tions means «royal residence, royalty, glory, divine glory». (JASTROw, A Dictionary of the Targumim... 1573).

${ }^{45} \mathrm{Tg}$. Neof. 12:12-13, in McNamara, Hayward, Targum Neofiti 1... 47-48, and МАсно, Neophiti $1 . . .437$.

${ }^{46}$ Corroborating this text with Jn 1:4-9 (esp. 9) and IP 1,1, one may find that Christian and Jewish communities developed various speculations about the divine light of the first day of creation and its presence within the created universe. These speculations may further be connected with the later Byzantine interest for the uncreated energies or grace and their manifestations within the creation. 
was revealed against the Egyptians at midnight: his hand slew the firstborn of the Egyptians and his right hand protected the first-born of Israel ... The fourth night: When the world reaches its appointed time to be redeemed: the iron yokes shall be broken [cf. Isa 9:4; 10:27 etc. and Jer 28:2-14], and the generations of wickedness shall be blotted out, and Moses will go up from the desert <and the king Messiah [מל משיז משיחי] from the midst of Rome>. [...] and his Memra (מימר) will lead between the two of them, and I and they will proceed together. This is the night of the Passover to the name of the Lord [cf. Ex 12:11]; it is a night reserved and set aside for the redemption of all Israel, throughout their generations. ${ }^{47}$

The passage thus depicts Yahweh's economy, if one can use this Greek term expressing God's manifestation in the world, a manifestation expressly guided by a soteriological goal. All the four manifestations of God in four different nights reflect the gradual illumination of creation accomplished in the final appearance of the Word at the Eschaton, when he will come in the company of Moses and the Messiah. While the Word is identified at the beginning of the fragment with the light of the first day of creation, at the end of the world the Word will reveal himself during the night of the Passover. As a consequence, it seems that the Targum Neofiti 1 preserves a special tradition in which the end of the actual world and the beginning of the eschatological one will happen on a Paschal night. ${ }^{48}$

In a different manner, yet emphasizing the same conception as that of Neofiti 1, Targum Pseudo-Jonathan on Exodus changes Exodus 12:11-12 («and you shall eat it [the lamb] hurriedly. It is the Passover of the Lord. For I will pass through the land of Egypt that night») to the following:

And you shall eat in the haste of the Shekinah (שכבינת) of the Lord of the world, because it is a mercy from before the Lord for you. On that night I will be revealed in the land of Egypt in the Shekinah (שכבינת) of my Glory ("קרי"), and with me there will be ninety thousand myriads of destroying angels. ${ }^{49}$

${ }^{47} \mathrm{Tg}$. Neof. 12:42, in McNamara, HaYward, Targum Neofiti 1... 52-53; Macho, Neophiti 1... 441-442. It is worth mentioning that, in Macho's edition, McNamara preferred to translate מץן גו רופז through «from on high» instead of «from the midst of Rome». He is in agreement with Macho's «de lo alto» (MACHO, Neophiti 1... 78) and Le Déaut's «d'en-haut» (Ibid. 313). See also the classical study on the theme of the four nights, LE DÉAUT, La nuit pascale...

${ }^{48}$ Compare with the Christian documents mentioned above. Cf. Hippolytus, Comm. Dan 4, $55 \mathrm{ff}$.

${ }^{49}$ Tg. Ps-J. 12:11-12, in M. MAHER, Targum Pseudo-Jonathan: Exodos (The Aramaic Bible. The Targums. Vol. 2) (Collegeville, 1994) 191. Cf. J. W. Etheridge, The Targums of Onkelos and Jonathan Ben Uzziel on the Pentateuch with the Fragments of the Jerusalem Targum (New York, 1968), 457. Also, see manuscript Add. 27031 of Tg. Ps-J. from the British Museum in R. LE DÉAut, Targum du Pentateuque (Tome II. 
Once again, glory-language finds its place in the paschal discourse. Also, in 12:23, the glory (מרי) is the agent which strikes the Egyptians, while the «Memra (מימר) of the Lord will protect the door and will not allow the Destroying Angel to enter and smite your houses» ${ }^{50}$ However, the passage does not make clear whether it is the glory or the destroying angel that strikes the Egyptian first-born. Finally, Exodus 12:29 introduces a third destroying agent, the Word of Yahweh: «In the middle of the night of the fifteenth (of Nissan) the Memra (מימרא) of the Lord slew all the first-born in the land of Egypt». ${ }^{51}$ It is significant to note that, since the Babilonian Targum does not employ glory-language when discussing the Passover, it follows that glorylanguage reflects a Palestinian development.

As a partial conclusion, one might therefore suppose that certain rabbinic writings associate the festival of Pesach with the expectation of a salvific theophany, be it that of Yahweh, that of his Word or Light, or that of his Shekinah.

\section{Conclusion}

Documentary evidence seems to lead to the hypothesis that the divine salvific glory was an emblematic expectation in Passover ritual traditions of the Second Temple of Jerusalem and both rabbinic and Christian Paschal traditions preserved it as a [or possibly even the] central assumption of their theologies. Moreover, at least for the Christian and rabbinic traditions, the Festival of Pascha was the privileged time for the divine descent and manifestation. Thus, the present study proposes the model of a two-branched theological tradition - kabod/glory-soteriology — developed from a common trunk. While this trunk points to the shared use of words such as «glory», «light», or «Lord», the Christian communities make a radical semantic shift at the level of theory and worship by identifying Christ with the divine agent that comes in glory (i.e., Yahweh, Shekinah, or the Word of Yahweh). This shift may have occurred earlier than A.D. 70 (or, at least at some point within

Exode et Lévitique) (Paris, 1979) (SC, 256) 87). For the Aramaic text, see M. GINSBURGER, Pseudo-Jonathan. Thargum Jonathan ben Usiël zum Pentateuch (Berlin, 1903) or D. RIEDER, Pseudo-Jonathan: Targum Jonathan ben Uziel on the Pentateuch Copied from the London MS [British Museum Add. 27031] (Jerusalem, 1974) and E. G. CLARKE, Targum Pseudo-Jonathan of the Pentateuch: Text and Concordance (Hoboken,

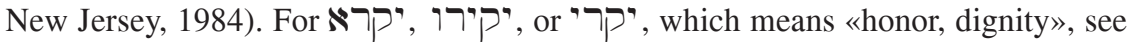
JASTROW, A Dictionary... 592.

${ }^{50}$ Tg. Ps-J. 12:23, in MAHer, Targum Pseudo-Jonathan... 192; cf. ETHERIDGe, The Targums... 476-477.

${ }^{51}$ Tg. Ps-J. 12:29, in MAher, Targum Pseudo-Jonathan... 193; cf. Etheridge, The Targums... 447. It is worth mentioning that the destroying agent in Tg. Onq. and Tg. Neof., in accordance with the biblical Ex 12:29, is Yahweh. 
the first century), since several early Christian texts identify Christ with Yahweh or the Lord of Glory, one of Yahweh's Old Testament titles.

From a mystical perspective, all three forms of the Paschal festival (Second Temple, Christian, and rabbinic) reflect the expectation to see God and be saved, which perhaps is the most important goal of every form of mysticism. A noteworthy feature of the Paschal festival is that the practical method of this form of mysticism is one performed by a group or community, not by an isolated individual. Some ritual acts such as the repentance pertaining to the Day of Atonement, or the Jewish and Christian fasting periods, the Paschal vigil, and the whole Paschal ritual of gestures, hymns, and homilies seem to play a similar role as the ascetic exercises: they prepare the individual for the divine vision of the kabod. However, it seems that the Paschal celebration is a form of group-mysticism, and it does not seem to be unique. The liturgical celebration of the Sabbath Sacrifice in the community of Qumran might be also seen as a type of group-mysticism. Likewise, the Christian liturgy, as one can see in many scholarly investigations, may also be regarded as a form of community-oriented mysticism. ${ }^{52}$

${ }^{52}$ See, for instance, L. Schiffman, The Dead Sea Scrolls and the Early History of Jewish Liturgy // The Synagogue in Late Antiquity / Ed. L. A. Levine (Philadelphia, 1984) 33-48; C. Newsom, Songs of the Sabath Sacrifice: A Critical Edition (Atlanta, 1985); M. BARKer, The Gate of Heaven: The History and Symbolism of the Temple in Jerusalem (London, 1991); S. ReIf, Judaism and Hebrew Prayer: New Perspectives on Jewish Liturgical History (Cambridge, 1993); D. K. FALK, Daily, Sabbath, and Festival Prayers in the Dead Sea scrolls (Leiden-Boston, 1998); A. Golitzin, Liturgy and Mysticism: The Experience of God in Eastern Orthodox Christianity // Pro Ecclesia VIII.1 (1999) 159-186; see also Golitzin's idea that the angelic hierarchy is a mirror and shaper of the soul in A. Golitzin, Dionysius Areopagites in the Works of Saint Gregory Palamas: On the Question of a «Christological Corrective» and Related Matters // SVTQ 46.2/3 (2002) 163-190; D. K. FalK, F. García-MartíNEZ, E. M. Schuller (eds.), Sapiential, Liturgical, and Poetical Texts from Qumran: Proceedings of the Third Meeting of the International Organization for Qumran Studies, Oslo 1998. Published in memory of Maurice Baillet (Leiden-Boston, 2000); M. BARKer, The Revelation of Jesus Christ: Which God Gave to Him to Show to His Servants what Must Soon Take Place [Revelation I.I] (Edinburgh, 2000) Esp. «Excursus: Parousia and Liturgy», 373-388; C. H. T. Fletcher-Louis, All the Glory of Adam. Liturgical Anthropology in the Dead Sea Scrolls (Leiden, 2002); G. ScHIMANOWSKI, Die himmlische Liturgie in der Apokalypse des Johannes: die frühjüdischen Traditionen in Offenbarung 4-5 unter Einschluss der Hekhalotliteratur (Tübingen, 2002); M. BARKer, The Great High Priest: The Temple Roots of Christian Liturgy (Edinburgh, 2003); The Dead Sea Scrolls as Background to Postbiblical Judaism and Early Christianity: Papers from an International Conference at St. Andrews in $2001 /$ Ed. J. R. Davila (Leiden-Boston, 2003); R. Elior, The Three Temples: On the Emergence of Jewish Mysticism (Oxford-Portland, 2004). 
Based on the assumptions of this study, several conclusions may be drawn. First, regarding the roots of glory-soteriology, it seems that a tradition that ascribed salvific power to the divine kabod existed in Second Temple Judaism and this position probably had its roots in the First Temple period. The main element of this theological position was that salvation comes through the manifestation of God's glory and consists of living before the divine Face.

Second, documents pertaining to the Second Temple period, such as Philo's writings, associate the vision of light with the Passover festival. One also may suppose that early rabbinic texts, such as Mishnah Pesachim and the Targums Neofiti 1 and Pseudo-Jonathan, preserve a tradition originating within the Second Temple period.

Third, Christian authors, such as Melito and Pseudo-Hippolytus, point to the Christian expectation of divine light at the time of the Paschal festival. As an important innovation, a semantic import occurs within the old system of meanings: now, Yahweh's expected theophany is the second coming, or the Parousia, of the resurrected Christ.

Fourth, the Christian and rabbinic Paschal expectations of the descent of the divine light most probably constitute two separate developments of previously similar expectations at the Passover festival observed during the Second Temple period.

Finally, the Jewish and Christian Festivals of Pascha may be regarded as forms of a special sort of mysticism, liturgical and community-oriented in its nature, offering the hope of salvation for everyone, rather than being the privilege of special individuals.

\section{ABSTRACT}

Two of the oldest Christian Paschal homilies, one by Melito of Sardis and the other of unknown origin (preserved under the names of Hippolytus of Rome and John Chrysostom), testify to the expectation of the descent of the divine and salvific glory during the Paschal night. I would call the theological doctrine behind this liturgical practice glory-soteriology or kabod-soteriology. Rabbinic materials such as the targums Neofiti 1 and Pseudo-Jonathan attest to a similar expectation on the night of the festival of Pesach. The salvific power of this glory seems to constitute the first rationale for this expectation, and the Festival of Pascha the privileged time for the divine descent and manifestation. Since further investigation identifies similar elements in the writings of Philo of Alexandria, the present study proposes what might be called a «two-branched» theory: one might reasonably suppose that both the Christian and the Jewish-rabbinic expectations of the descent of the salvific glory of Pascha may constitute two different developments of a common matrix in the Second Temple festival of Passover. Major doctrinal and ritual shifts emerge in Christian worship where Jesus Christ took the place of Yahweh or of his Word. 